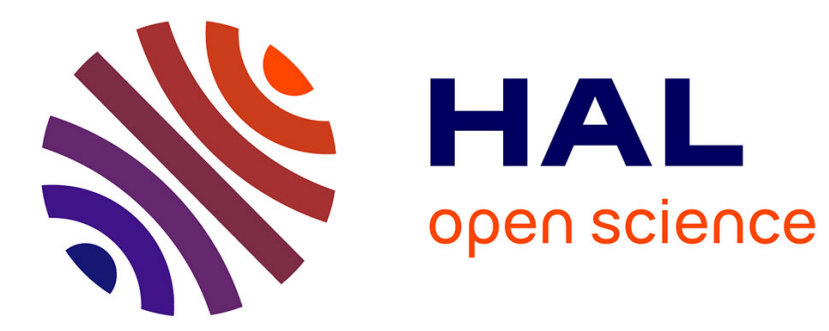

\title{
Distribution of Sulfate-Reducing Communities from Estuarine to Marine Bay Waters
}

Yannick Colin, Marisol Goñi, C. Gassie, E. Carlier, Mathilde Monperrus, Remy Guyoneaud

\section{To cite this version:}

Yannick Colin, Marisol Goñi, C. Gassie, E. Carlier, Mathilde Monperrus, et al.. Distribution of Sulfate-Reducing Communities from Estuarine to Marine Bay Waters. Microbial ecology, 2017, 73 (1), pp.39-49. 10.1007/s00248-016-0842-5 . hal-01499135

\section{HAL Id: hal-01499135 \\ https://hal.science/hal-01499135}

Submitted on 26 Sep 2017

HAL is a multi-disciplinary open access archive for the deposit and dissemination of scientific research documents, whether they are published or not. The documents may come from teaching and research institutions in France or abroad, or from public or private research centers.
L'archive ouverte pluridisciplinaire HAL, est destinée au dépôt et à la diffusion de documents scientifiques de niveau recherche, publiés ou non, émanant des établissements d'enseignement et de recherche français ou étrangers, des laboratoires publics ou privés.

\section{다(1)(2)}

Distributed under a Creative Commons Attribution - ShareAlikel 4.0 International 


\title{
Distribution of Sulfate-Reducing Communities from Estuarine to Marine Bay Waters
}

\author{
Yannick Colin $^{1,2}$ • Marisol Goñi-Urriza ${ }^{1}$ - Claire Gassie ${ }^{1}$ - Elisabeth Carlier ${ }^{1}$ • \\ Mathilde Monperrus $^{3} \cdot$ Rémy Guyoneaud ${ }^{1}$
}

Received: 23 May 2016 / Accepted: 17 August 2016/Published online: 31 August 2016

(C) Springer Science+Business Media New York 2016

\begin{abstract}
Estuaries are highly dynamic ecosystems in which freshwater and seawater mix together. Depending on tide and river inflows, particles originating from rivers or from the remobilization of sediments accumulate in the water column. Due to the salinity gradient and the high heterotrophic activity in the estuarine plume, hypoxic and anoxic microniches may form in oxygenated waters, sustaining favorable conditions for resuspended anaerobic microorganisms. In this context, we tested the hypothesis that anaerobic sulfate-reducing prokaryotes may occur in the water column of the Adour River. Using 16S ribosomal RNA (rRNA) and $d s r \mathrm{AB}$-based terminal restriction fragment length polymorphism (T-RFLP) techniques, we characterized total prokaryotic and sulfatereducing communities along a gradient from estuarine to marine bay waters. Sulfate-reducing prokaryotes were further characterized by the description of $d s r \mathrm{~B}$ genes and the cultivation of sulfidogenic anaerobic microorganisms. As a result, physical-chemical parameters had a significant effect on water bacterial diversity and community structure along the studied
\end{abstract}

Electronic supplementary material The online version of this article (doi:10.1007/s00248-016-0842-5) contains supplementary material, which is available to authorized users.

Yannick Colin

colin.yannick@gmail.com

1 Equipe Environnement et Microbiologie, IPREM UMR CNRS 5254, Université de Pau et des Pays de l'Adour, IBEAS, BP 1155, 64013 Pau Cedex, France

2 Present address: INRA, UMR 1136 INRA/Université de Lorraine, Interactions Arbres Micro-organismes, Centre de Nancy, 54280 Champenoux, France

3 Laboratoire de Chimie Analytique Bio-Inorganique et Environnement (LCABIE), IPREM UMR CNRS 5254, Université de Pau et des Pays de l'Adour, Pau, France gradient. The concentration of cultured sulfidogenic microorganisms ranged from 1 to $60 \times 10^{3}$ cells $1^{-1}$ in the water column. Sulfate-reducing prokaryotes occurring in estuarine waters were closely related to microorganisms previously detected in freshwater sediments, suggesting an estuarine origin, mainly by the remobilization of the sediments. In the marine bay station, sediment-derived sulfate-reducing prokaryotes were not cultured anymore, probably due to freshwater dilution, increasing salinity and extended oxic stress. Nevertheless, isolates related to the type strain Desulfovibrio oceani were cultured from the diluted plume and deep marine waters, indicating the occurrence of autochthonous sulfatereducing bacteria offshore.

Keywords Sulfate-reducing bacteria $\cdot$ Sediments remobilization $\cdot$ Estuarine plume $\cdot$ Marine bay waters

\section{Introduction}

Sulfate-reducing prokaryotes (SRP) constitute a diverse group of bacteria that are widespread in nature [40]. In anoxic environments such as estuarine sediments, SRP are abundant and largely involved in organic matter mineralization by oxidizing low molecular weight carbon sources. This functional group preferentially uses oxidized sulfur compounds (i.e., sulfate, thiosulfate, and sulfite) as terminal electron acceptors [24]. Nevertheless, many SRP are also able to use other electron acceptors (i.e., nitrate) or fermentation. Even if this functional group is commonly associated with oxygen-deprived environments, SRP have been detected in continuously or temporarily oxic habitats such as microbial mats, wastewater treatment systems, or aquatic plant roots where anoxic microniches can be created $[4,7,21,22,34]$. SRP have also been identified in the water column of the oxygen minimum zone in the 
Pacific Ocean, where sulfate reduction was found to be active [5]. Desulfovibrio strains isolated from such samples were reported to survive in fluctuating oxygen regimes and to resume their sulfate-reducing activity immediately upon anaerobiosis [13]. In spite of these studies, there is limited knowledge regarding the distribution and the dynamic and diversity of sulfate-reducing communities in coastal waters, which are characterized by high heterotrophic activities.

Estuaries are complex ecosystems [3, 10], where combined variations in temperature, freshwater discharge, seawater intrusion, circulation, and biological processes produce strong dissolved oxygen gradients $[12,48]$. Notably, aerobic respiration removes oxygen from the water column while consuming organic matter from phytoplankton production, river inputs, and detritus. In many eutrophied estuaries, elevated phytoplankton production is thought to be responsible for expansion of bottom-water anoxia [38]. Vertical salinity stratification further stimulates the development of fluctuating estuarine bottom-water hypoxia and anoxia and sustains favorable conditions for anaerobes by inhibiting the mixing of water bodies [39, 44, 46]. Additionally, hydrodynamic forces such as waves, tides, and currents along with dredging and ship traffic remobilize large amounts of sediments and their associated microorganisms into oxic waters. Depending on their size and density, anaerobes and sediments are lifted up from the bottom and may remain in suspension for several hours or even much longer in estuarine waters $[11,41]$. As a consequence, SRP developing preferentially in anoxic sediments are expected to occur in the water column for an undetermined length of time and to be transported offshore.

In this context, we tested the hypothesis that anaerobic sulfate-reducing prokaryotes may inhabit the water column of the Adour estuarine plume at different depths. Sampling stations were located in a gradient from the inner part of the estuary to marine bay waters. Water samples were collected 10 days after a flood event in the Adour river plume, promoting massive photosynthetic bloom in the estuarine plume [36]. The structure of total bacterial communities was assessed by terminal restriction fragment length polymorphism (T-RFLP) fingerprint of $16 \mathrm{~S}$ ribosomal RNA (rRNA) gene, while sulfatereducing communities were investigated through the $d s r \mathrm{AB}$ gene encoding for dissimilatory sulfite reductase, specific to sulfate reducers. In parallel, a 384-well microplate technique was adopted for the isolation of sulfidogenic microorganisms, including SRP. Even if coastal waters do not apparently maintain all conditions required for anaerobic growth, SRP were detected from estuarine to marine bay waters by both culturedependent and culture-independent approaches. Based on taxonomic assignment of isolates and clones sequences, the occurrence of SRP as autochthonous and allochthonous populations in the water column is discussed.

\section{Material and Methods}

\section{Sample Collection and Nucleic Acid Extraction}

The Adour estuary is located on the South French Atlantic coast and freshwater is flowing into the Gulf of Biscay. Its mean annual water discharge is estimated around $300 \mathrm{~m}^{3} \mathrm{~s}^{-1}$ with peaks up to $2000 \mathrm{~m}^{3} \mathrm{~s}^{-1}$. At the channelized mouth, the width of the estuary does not exceed $150 \mathrm{~m}$ and the depth is $12 \mathrm{~m}$. In May 2010, water was sampled at low tide in the concentrated plume (PC), diluted plume (PD), and in a marine station (MA) (Fig. 1). An additional sampling station, located in the inner part of the estuary (ES) was exclusively used for the isolation of sulfidogenic microorganisms. Water samples were collected at different water depths using a rosette sampler equipped with GoFlow and Niskin bottles and a CTD unit (Sea-Bird Electronics Inc, USA) for monitoring the salinity, temperature, oxygen, and turbidity values. For each sampling plot, samples were collected in triplicates from individual bottles and filtered through $0.22 \mu \mathrm{m}$ pore size filter (cellulose nitrate, Sartorius) until complete saturation. Volumes collected for each sampling station are summarized in Table 1. Filters were immediately frozen in liquid nitrogen and stored at $-80^{\circ} \mathrm{C}$ until molecular analyses. Total DNA extractions were subsequently performed in triplicates using the fast RNA Prosoil direct kit (MP Biomedical) according to the manufacturer's guidelines. The concentration and quality of total DNA were checked on $0.8 \%$ agarose gels stained with ethidium bromide.

\section{DNA Amplification and Molecular Fingerprinting of Bacterial Communities}

Total bacterial communities and sulfate-reducing bacteria were characterized using t-RFLP on 16S rRNA and $d s r \mathrm{AB}$ genes. For each sampling point, triplicates samples resulting from the three DNA extractions were processed independently. For total bacterial communities PCR amplifications were performed using the primer set 63F/1387R [31]. PCRs contained $200 \mathrm{nM}$ of each primer, $1 \times$ PCR buffer, $200 \mu \mathrm{M}$ of dNTPs, $1.5 \mathrm{mM} \mathrm{MgCl}_{2}$, and $1 \mathrm{U}$ of Taq Eurobio in a final volume of $50 \mu \mathrm{l}$. For sulfate-reducing communities, $d s r \mathrm{AB}$ genes were amplified by nested PCRs with the DSR1F/4R and the $619 \mathrm{AF} / 1905 \mathrm{BR}$ primers set [16]. PCR reactions were performed as previously described by Giloteaux et al. [16]. For each analysis, the forward primer was fluorescently labeled with FAM fluorochrome (6-carboxyfluorescein acetoxymethyl-ester). Amplified gene fragments were checked on $0.8 \%$ agarose gel and purified using the GFX DNA and Gel Band Purification kit (GE Healthcare). TRFLP analyses were performed as previously described elsewhere [17], using $3 \mathrm{U}$ of Hinfl and HaeIII (New England Biolabs) as restriction enzymes for $16 \mathrm{~S}$ rRNA gene, and $3 \mathrm{U}$ 
Fig. 1 Water sampling locations. Sampling stations are referred as follow: inner-estuary station $(E S)$, concentrated estuary plume station $(P C)$, diluted estuary plume station $(P D)$, and marine station $(M A)$

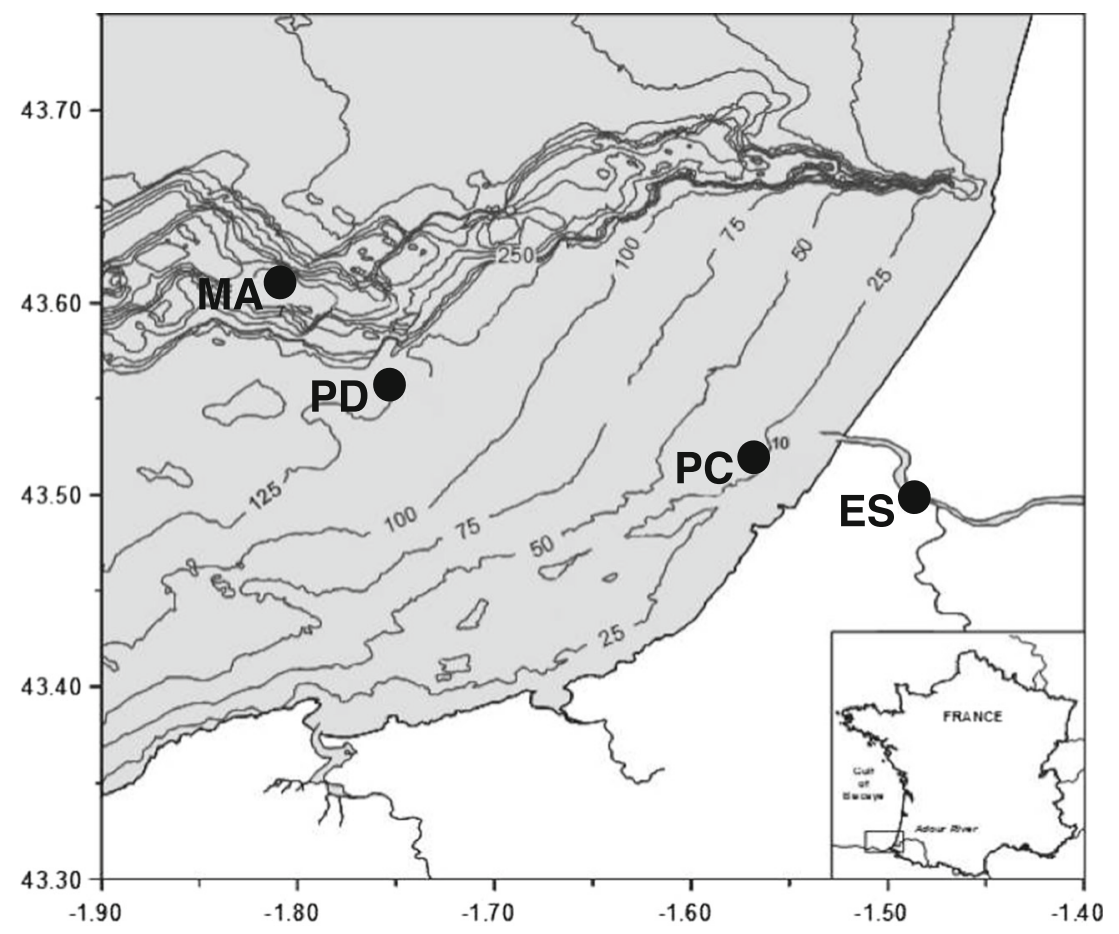

of Bsp1286I and HpyCH4-IV (New England Biolabs) as restriction enzymes for $d s r \mathrm{AB}$ genes. T-RFLP profiles were aligned using the T-align software [47] and the confidence interval was set to 0.5 . Relative abundances (i.e., normalized to the total fluorescence peak height) were calculated and TRFs that displayed less than $1 \%$ of the total fluorescence were removed before recalculation of relative abundances. Numbers of T-RFs and Shannon indexes were estimated to evaluate the bacterial community richness and diversity, respectively, and were compared using a one-way analysis of variance (ANOVA). Canonical correspondence analysis (CCA) was used to characterize the relationships between bacterial community profiles and physicochemical parameters using the $\mathrm{R}$ package FactoMineR [30]. Ordination and PERMANOVA (adonis) testing was performed using the vegan package 2.2-1 in R [37]. Putative identifications of selected T-RFs were performed by in silico restriction of the data using TRiFLe [25]. Last, mantel tests (1000 permutations, Spearman correlations) were performed (vegan package 2.21 in R) in order to test correlations physicochemical parameters and the relative abundance of specific terminal-restriction fragment, based on Bray Curtis distances dissimilarity matrices.

\section{dsrAB Clone Library and Sequence Analysis}

A $d s r \mathrm{AB}$ clone library was performed using surface waters of the estuary plume stations (PC1 and PD1 samples) and marine water collected at $240 \mathrm{~m}$ depth (MA240 sample). Amplicons were ligated into the PCRTOPO 2.1 TA cloning vector
(Invitrogen, The Netherlands) and transformed into competent Escherichia coli TOP 10F' cells (Invitrogen, The Netherlands) according to the manufacturer's instructions. Positive transformants were randomly chosen and their inserts were PCR amplified using the M13F and M13R primers. Amplified gene fragments were checked on $0.8 \%$ agarose gel and were then sequenced. The $d s r \mathrm{AB}$ sequences were assembled by using the software Sequencher v4.1.4 and compared with those present in databank using the BLAST tool at NCBI. Clone sequences were deposited in the European Nucleotide Archive (ENA) with accession numbers HG932608-HG932652 and LT575364-LT575375.

\section{Isolation and Identification of Sulfidogenic Bacteria}

A dilution-to-extinction procedure in 384-well microplates for sulfidogenic microorganisms [6] was applied on the 12 water samples. Culture medium was prepared with $0.2 \mu \mathrm{m}$ filtered environmental water collected upstream the Adour river mouth and supplemented with $20 \mathrm{mM}$ of sulfate as electron acceptor and a mixture of acetate, lactate, glycerol, and pyruvate ( $5 \mathrm{mM}$ each) as electron donors. In addition, growth medium was amended with $20 \mathrm{~g} \mathrm{l}^{-1}$ of $\mathrm{NaCl}$ for PC, PD, and MA samples. Medium was sterilized $20 \mathrm{~min}$ at $121{ }^{\circ} \mathrm{C}$ in $100 \mathrm{~mL}$ serum bottles closed with butyl stoppers and an aluminum crimp and was immediately flushed under nitrogen gas flow. Prior to use, $\mathrm{FeSO}_{4} \cdot 7 \mathrm{H}_{2} \mathrm{O}, 1 \mathrm{mM}$, was added to monitor sulfidogenic growth by iron sulfide precipitation during incubations, whereas $\mathrm{Na}_{2} \mathrm{~S}_{2} \mathrm{O}_{4}$ at $200 \mu \mathrm{M}$ was added to achieve reduced conditions. All samples were diluted 10- and 
100 -fold with culture medium ( $40 \mathrm{~mL}$ final volume) and were dispensed in 384-well microplates (1 microplate per dilution, $100 \mu \mathrm{L}$ per well). Microplates were then placed in a BD GasPak $^{\mathrm{TM}}$ EZ Gas Generating Systems at $20{ }^{\circ} \mathrm{C}$. After an incubation time of 3 weeks, the concentration of viable sulfidogenic bacteria was estimated according to the dilution and the number of positive wells (black iron sulfide) per microplate. Then, isolates were recultured and purified in fresh media by successive dilutions. For strains identification based on 16S rRNA sequences, direct PCR amplifications were achieved with the $63 \mathrm{~F} / 1387 \mathrm{R}$ primer set as described above. Sequences were assembled by using the software Sequencher v4.1.4 and compared with those present in databank using the BLAST tool at NCBI. 16S rRNA gene sequences were deposited in the ENA with accession numbers HG932653-HG932701 and LT575376LT575459. Moreover, bacterial isolates closely related to Desulfovibrio oceani were tested for their sensivity to oxygen (see Electronic supplementary material for detailed method description).

\section{Results}

\section{Main Physical and Chemical Parameters}

Physico-chemical parameters measured along the Adour estuary plume are summarized in Table 1. The Adour river flow recorded in May $2010\left(\sim 450 \mathrm{~m}^{3} \mathrm{~s}^{-1}\right)$ was slightly higher than the average annual discharge. As expected, ES station contained more particulate organic carbon, particles in suspension, nitrate, and silica than other samples. Further in the gradient, surface waters of the concentrated and diluted plume (PC1 and PD1 samples) exhibited the highest turbidity (4.85 and $2.13 \mathrm{NTU}$ ) and the lowest salinity values ( 27 and $31 \mathrm{~g} \mathrm{~L}^{-1}$ ), highlighting low-density estuarine freshwater flowing over higher-density seawater. In the marine station, an increase of the water turbidity and ammonium, nitrate and silica concentrations at $240 \mathrm{~m}$ water depth (MA240 sample) was observed. Last, the oxygen content was measured in the water column and was reported constant $\left(\sim 250 \mu \mathrm{mol} \mathrm{L}^{-1}\right)$ along the estuarine-marine gradient, excepted for MA800 sample $\left(172 \mu \mathrm{mol} \mathrm{L}^{-1}\right)$ (Table 1). The dissolved oxygen saturation concentration, which is a function of temperature and salinity, ranged between 77 and $79 \%$ in ES samples and was higher than $89 \%$ in PD1, PD13, PD55, MA5, MA22, and MA240 samples.

\section{Total Bacterial Communities}

T-RFLP bacterial fingerprinting was performed for bacterioplankton communities analysis. Based on 16S rRNA gene, a total of 197 and 119 Terminal-Restriction Fragment (T-RFs) were detected respectively with the HaeIII and Hinfl 
restriction enzymes and the bacterial richness ranged from 21 to 43 T-RFs per sample (Table 2). Although the bacterial richness did not vary significantly within the samples (one-way ANOVA, $P<0.05$ ), the total bacterial diversity in MA240 and MA800 samples was significantly higher as compared with MA5 and MA22 samples (one-way ANOVA, $P<0.05$ ) (Table 2). Strong correlation between the environmental parameters and the bacterial diversity was observed (Mantel test, $r=0.84, P<0.001)$. To identify environmental parameters that significantly explained the variance in the total bacterial community, canonical correspondence analyses (CCA) were performed on T-RFLP restriction patterns obtained with HaeIII and Hinfl (Fig. 2a; Fig. S1a). Samples MA240 and MA800 were excluded from the multivariate analyses as they clearly separated from other samples and masked differences between other samples. These latter were positively correlated with water depth and phosphate content (data not shown). Based on Hinfl restriction patterns, the first and the second axes of the ordination plot explained, respectively, 19.4 and $12.8 \%$ of the total variance (Fig. 2a). All the environmental variables tested were observed to significantly affect bacterial communities (Adonis, $P<0.001$ ). On the ordination plot, PC samples correlated positively with the water turbidity and the nitrate and silica content. In contrast, other environmental factors such as salinity, nitrite, depth, and temperature were positively correlated with the bacterial community composition and partly explained the differentiation between PD1, PD13, and MA5 samples and PD55 and MA22 samples along axis 2 (Fig. 2a).

Based on Hinfl restriction patterns, T-RFs at 76, 259, 261, 264, 289, and $290 \mathrm{bp}$ accounted for 51.6-74.1\% of the total fluorescence in all the samples. Only the marine samples, MA240 and MA800 did not exhibit such dominance of a few T-RFs (Fig. 3a). T-RFs at 261 and 290 bp, which could not be identified by in silico restrictions, constituted around one third of the total bacterioplankton in the PC station. Based on Spearman correlations, these taxa were positively correlated to suspended particulate matter (SPM) and particulate organic carbon (POC) (Table S1) $(P<0.001)$. In PD samples, the relative abundance of T-RFs at 76 and 289 bp increased (Fig. 3a). T-RF at 289 bp could be related to the SAR11 clade while no putative identification could be achieved for the T-RF at 76 bp. T-RF at 289 bp was found to be negatively correlated to SPM concentration and POC contents $(P<0.001)$, while T-RF at 76 bp was positively correlated to temperature and oxygen and negatively correlated to water depth and phosphate $(P<0.001)$ (Table S1).

\section{Sulfate-Reducing Communities}

\section{T-RFLP Bacterial Fingerprinting}

The $d s r A B$ genes were successfully amplified along the studied gradient, except for the PD13, MA5, and MA22 samples. Using the Bsp1286I and HpyCH4-IV restriction enzymes, sulfate-reducing richness ranged from 7 to 22 T-RFs per sample (Table 2). A one-way ANOVA analysis showed that the diversity and richness indices were significantly reduced in marine waters as compared with other samples (Table 2). Moreover, Mantel test showed that variation across samples was significantly correlated with environmental parameters $(r=0.32, P<0.01)$. A CCA analysis was applied independently on the T-RFLP profiles generated by the enzymes

Table 2 Diversity and richness estimates obtained through T-RFLP analysis of total bacterial communities (16S rRNA) and sulfate-reducing communities ( $d s r \mathrm{AB}$ genes)

\begin{tabular}{|c|c|c|c|c|c|c|c|c|}
\hline \multirow[t]{3}{*}{ Samples } & \multicolumn{4}{|c|}{ Total bacterial communities } & \multicolumn{4}{|c|}{ Sulfate-reducing communities } \\
\hline & \multicolumn{2}{|l|}{ HaeIII } & \multicolumn{2}{|l|}{$\operatorname{HinfI}$} & \multicolumn{2}{|l|}{ Bsp1286I } & \multicolumn{2}{|l|}{ HpyCH4-IV } \\
\hline & Sobs & Shannon & Sobs & Shannon & Sobs & Shannon & Sobs & Shannon \\
\hline PC1 & $39.67 \pm 2.19 \mathrm{a}$ & $3.09 \pm 0.05 \mathrm{abc}$ & $29.67 \pm 1.33 \mathrm{ab}$ & $2.82 \pm 0.05 \mathrm{abc}$ & $17.00 \pm 2.52 \mathrm{ab}$ & $2.53 \pm 0.10 \mathrm{a}$ & $22.67 \pm 3.48 \mathrm{a}$ & $2.72 \pm 0.16 \mathrm{a}$ \\
\hline PC5 & $38.00 \pm 1.53 \mathrm{a}$ & $2.99 \pm 0.02 \mathrm{bc}$ & $28.33 \pm 1.45 \mathrm{abc}$ & $2.70 \pm 0.04 \mathrm{bc}$ & $18.33 \pm 1.76 \mathrm{a}$ & $2.46 \pm 0.11 \mathrm{a}$ & $19.00 \pm 2.00 \mathrm{ab}$ & $2.50 \pm 0.15 \mathrm{a}$ \\
\hline PC24 & $36.33 \pm 0.67 \mathrm{a}$ & $3.09 \pm 0.02 \mathrm{ab}$ & $28.00 \pm 2.31 \mathrm{abc}$ & $2.88 \pm 0.07 \mathrm{ab}$ & $16.33 \pm 2.03 \mathrm{ab}$ & $2.35 \pm 0.14 \mathrm{a}$ & $18.67 \pm 0.88 \mathrm{ab}$ & $2.48 \pm 0.09 \mathrm{a}$ \\
\hline PD1 & $34.00 \pm 2.08 \mathrm{a}$ & $2.78 \pm 0.04 \mathrm{c}$ & $23.67 \pm 1.20 \mathrm{abc}$ & $2.56 \pm 0.02 \mathrm{c}$ & $17.67 \pm 0.88 \mathrm{abc}$ & $2.43 \pm 0.13 \mathrm{a}$ & $15.00 \pm 1.73 \mathrm{abc}$ & $2.05 \pm 0.37 \mathrm{a}$ \\
\hline PD13 & $32.67 \pm 1.76 \mathrm{a}$ & $2.89 \pm 0.01 \mathrm{bc}$ & $21.33 \pm 1.20 \mathrm{c}$ & $2.65 \pm 0.05 \mathrm{bc}$ & nd & nd & nd & nd \\
\hline PD55 & $38.00 \pm 1.15 \mathrm{a}$ & $3.08 \pm 0.05 \mathrm{abc}$ & $23.33 \pm 1.33 \mathrm{abc}$ & $2.70 \pm 0.09 \mathrm{bc}$ & $16.00 \pm 1.53 \mathrm{abc}$ & $2.47 \pm 0.13 \mathrm{a}$ & $14.67 \pm 1.76 \mathrm{abc}$ & $2.25 \pm 0.12 \mathrm{a}$ \\
\hline MA5 & $37.67 \pm 1.33 \mathrm{a}$ & $3.00 \pm 0.03 \mathrm{bc}$ & $23.00 \pm 0.58 \mathrm{abc}$ & $2.68 \pm 0.02 \mathrm{bc}$ & nd & nd & nd & nd \\
\hline MA22 & $31.33 \pm 3.18 \mathrm{a}$ & $3.01 \pm 0.10 \mathrm{bc}$ & $22.33 \pm 1.20 \mathrm{bc}$ & $2.61 \pm 0.03 \mathrm{bc}$ & nd & nd & nd & nd \\
\hline MA240 & $43.50 \pm 8.50 \mathrm{a}$ & $3.37 \pm 0.18 \mathrm{a}$ & $31.00 \pm 1.00 \mathrm{a}$ & $2.92 \pm 0.05 \mathrm{ab}$ & $7.67 \pm 0.33 \mathrm{c}$ & $1.73 \pm 0.12 b$ & $8.00 \pm 2.08 \mathrm{c}$ & $1.90 \pm 0.20 \mathrm{a}$ \\
\hline MA800 & $39.00 \pm 4.93 \mathrm{a}$ & $3.38 \pm 0.09 \mathrm{a}$ & $30.00 \pm 2.52 \mathrm{ab}$ & $3.01 \pm 0.09 \mathrm{a}$ & $10.67 \pm 0.88 \mathrm{bc}$ & $2.02 \pm 0.08 \mathrm{ab}$ & $11.00 \pm 1.00 \mathrm{bc}$ & $1.81 \pm 0.38 \mathrm{a}$ \\
\hline
\end{tabular}

Each value is the mean of replicates T-RFLP profiles ( \pm standard error of the mean). For each estimate, significant differences are presented by different letters $(P<0.05)$. Samples for which $d s r A B$ genes were not detected by $n d$ 


\section{A (16S - Hinfl)}

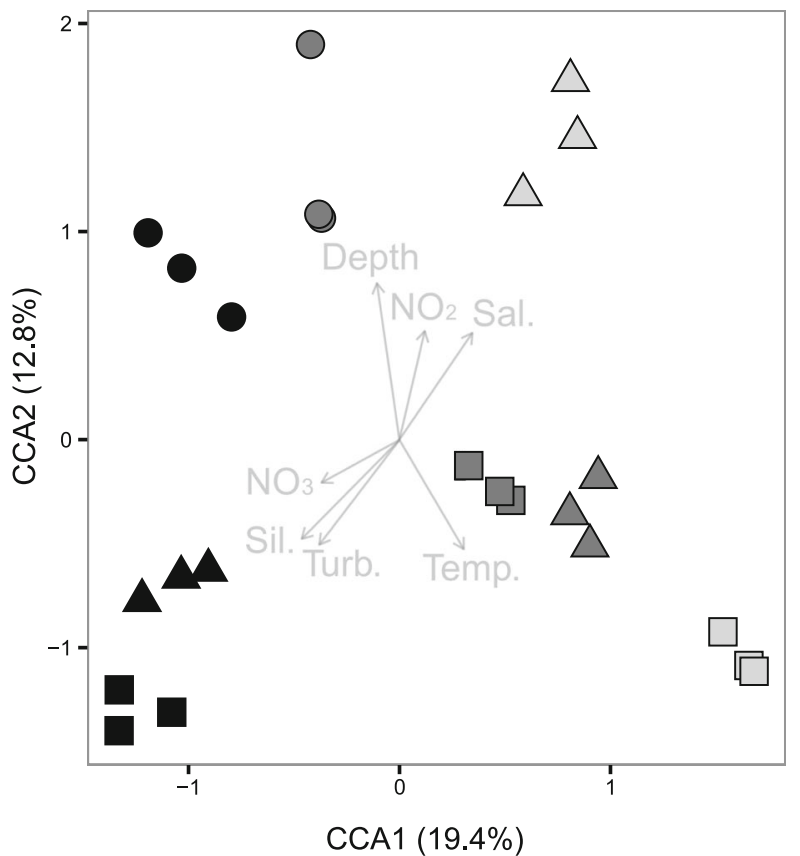

Fig. 2 Canonical correspondence analyses based on t-RFLP patterns of the 16S rRNA (a) and $d s r \mathrm{AB}$ (b) genes. T-RFLP profiles were achieved with the Hinfl restriction enzyme for 16S rRNA gene and with the Bsp 1286I restriction enzymes for $d s r \mathrm{~B}$ gene. Correlations between physicochemical parameters and CCA axes are represented by the length and angle of the arrows. Physicochemical factors are referred as
B (dsrB - Bsp1286I)

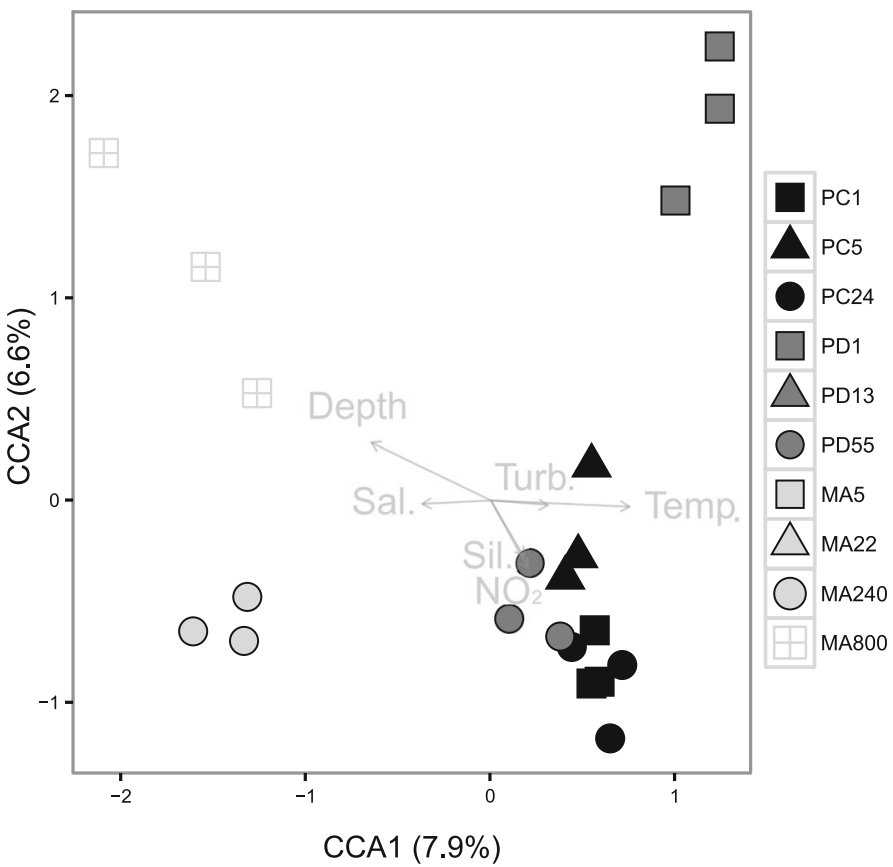

follow: temperature (Temp.), salinity (Sal.), turbidity (Turb.), nitrate $\left(\mathrm{NO}_{3}\right)$, nitrites $\left(\mathrm{NO}_{2}\right)$, silica $\left(\mathrm{Sil}\right.$.), and phosphate $\left(\mathrm{PO}_{4}\right)$. For $16 \mathrm{~S}$ rRNA gene, samples MA240 and MA800 were removed from the CCA analysis for a better visualization of the other samples on the ordination plot. For $d s r \mathrm{AB}$ genes, no gene amplification was detected for the PD13, MA5, and MA22 samples
Fig. 3 Relative abundance of the major 16S rRNA and $d s r \mathrm{AB}$ genes T-RFs occurring in the estuary-marine gradient. a Relative abundance of the major 16S rRNA gene T-RFs following digestion with Hinfl. Number in keys refers to T-RFs length in base pairs (bp). b Relative abundance of the major $d s r \mathrm{~B}$ gene T-RFs following digestion with Bsp1286I. Number in keys refers to T-RFs length in base pairs (bp)
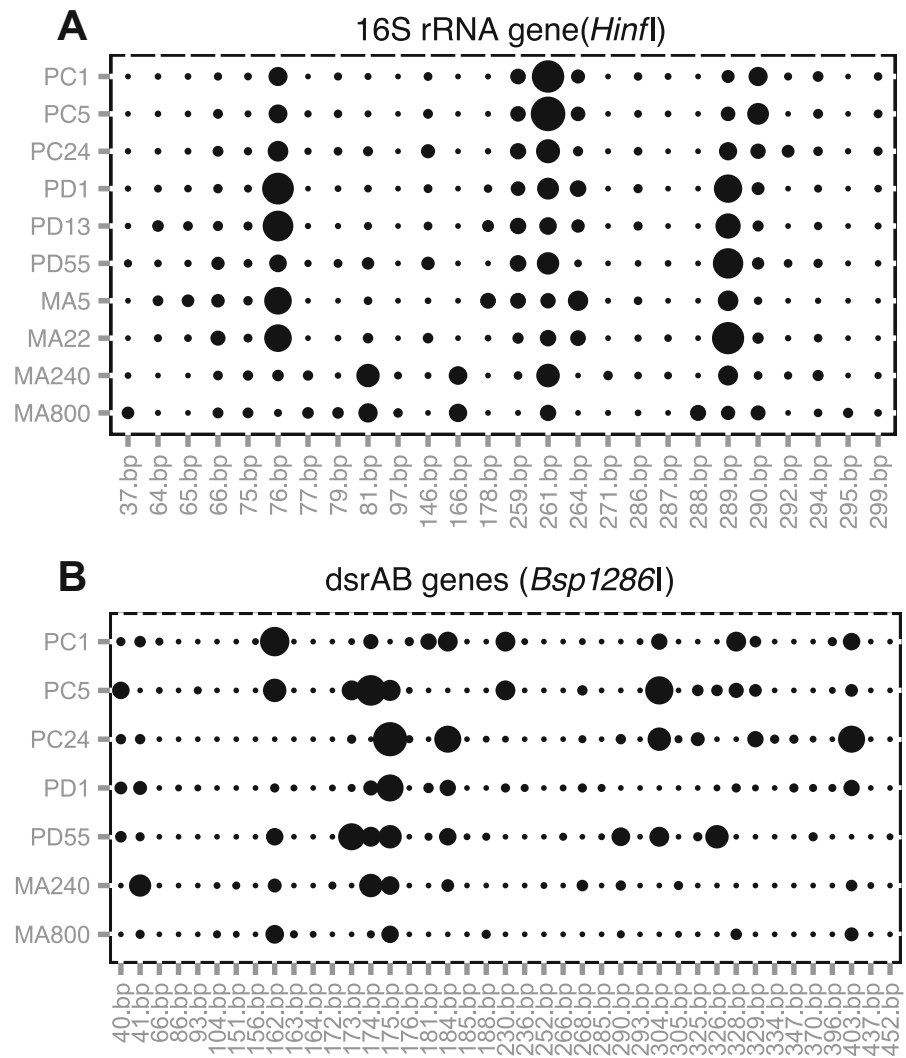

Relat.abund.
0
- 5
- 10
- 15
20

Relat.abund

- 2.5

- 5.0

7.5 
(Fig. 2b; Fig. S1b). Based on Bsp1286I restriction patterns, the two first axes explained, respectively, 7.9 and $6.6 \%$ of the total variance (Fig. 2b). As already reported with $16 \mathrm{~S}$ rRNA gene, sulfate-reducing communities from MA240 and MA800 samples clearly distinguished from other samples and were positively correlated with depth and salinity. In addition, PD1 samples clustered apart all other samples and did not correlated with any physical or chemical factor. The remaining samples grouped together and were positively correlated with temperature, water turbidity, nitrite, and silicate contents. A detailed analysis showed that the T-RFs at 41, $162,173,174$, and $175 \mathrm{bp}$ accounted for $9.2-39.9 \%$ of the total fluorescence in all the samples but could not be putatively identified (Fig. 3b). Links between the relative abundance of T-RFs and physical and chemical parameters were explored and summarized in Table S2. Notably, those major T-RFs were positively correlated with nitrite, nitrate, particles in suspension, and particulate organic carbon.

\section{dsrAB Genes Cloning}

Based on $d s r A B$ T-RFLP profiles and physico-chemical parameters, PC1, PD1, and MA240 samples were reported to differ significantly from each other. Thus, these later were used to further assess the diversity of the dissimilatory (bi)sulfite reductase genes using $d s r A B$ cloning and sequencing. A total of 57 $d s r \mathrm{AB}$ clones were recovered and rarefaction analysis indicated that the saturation plateau was not reached (data not shown). Taxonomic assignment of $d s r A B$ clones revealed that sequences detected in PC1 sample were mainly related to the Desulfobacteraceae and Desulfobulbaceae families (Fig. 4). Notably, several clone sequences from PC1 sample shared high sequence similarities with Desulfobulbus propionicus (Table 3). Further in the gradient, PD1 sample was mainly represented by non-affiliated clones. In addition, clone sequences related to the Desulfovibrionaceae and Desulfomicrobiaceae families were detected (Fig. 4; Table 3). Last, clone sequences retrieved from MA240 sample were mainly related to the Desulfobacteraceae and Desulfobulbaceae families but differed from those observed in PC1 sample (Fig. 4; Table 3).

\section{Diversity of Cultured SRP}

An isolation procedure for sulfidogenic microorganisms was carried out using a dilution-to-extinction technique in 384well microplates. In addition to all PC, PD, and MA samples, a sampling station (ES), located upstream of the concentrated estuarine plume, was also included in these experiments. Positive sulfidogenic growth was obtained for all samples in the gradient, except for PD13, MA5, and MA22 samples (which did not exhibit $d s r \mathrm{~B}$ gene amplification). Sulfidogenic microorganism concentration ranged from 1 to $16 \times 10^{3}$ cells $\mathrm{L}^{-1}$ in $\mathrm{PC} 1, \mathrm{PC} 5, \mathrm{PC} 24, \mathrm{PD} 1$, and PD55

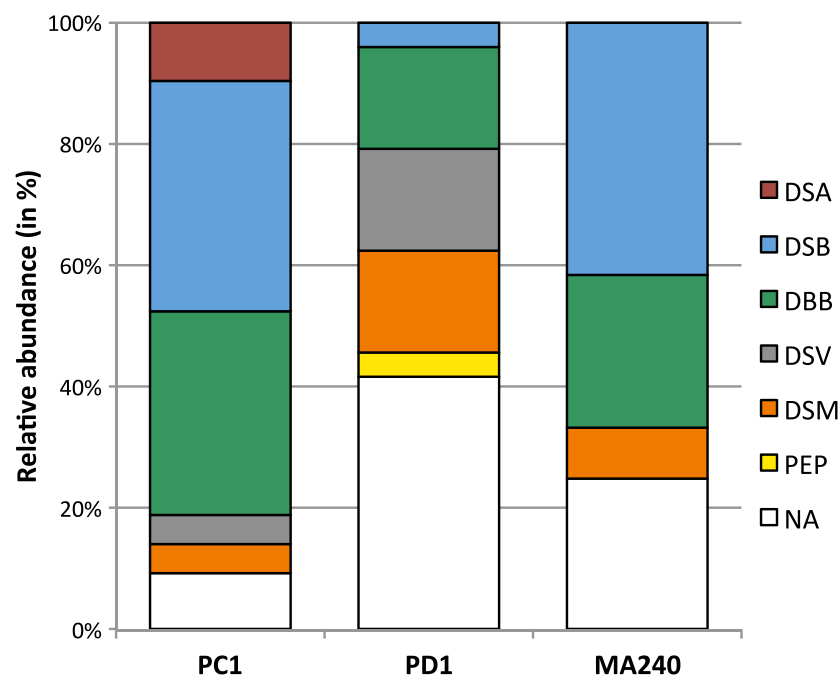

Fig. 4 Taxonomic affiliation of $d s r \mathrm{~B}$ clones at the genus levels. Bar charts of $d s r \mathrm{~B}$ clone libraries for the PC1 and PD1 and MA240 samples. Sulfate-reducing clones were affiliated to different sulfatereducing genera among the Desulfobacteraceae (DSB), Desulfobulbaceae (DBB), Desulfomicrobiaceae (DSM), Desulfovibrionaceae (DSV), Desulfoarculaceae (DSA), and Peptococcaceae (PEP) families. NA non-affiliated clones. See Table 3 for detailed taxonomic assignments

samples, while concentrations up to $60 \times 10^{3}$ cells $\mathrm{L}^{-1}$ were observed in ES1, ES6, and MA240 samples (Fig. 5). A total of 136 sulfidogenic strains were isolated and were identified based on partial 16S rRNA gene sequences. As a result, true SRP (i.e., respiratory based metabolism) accounted for 7 $40 \%$ of total sulfidogenic isolates among the samples (Fig. 5). Other sulfidogens (fermentative metabolism) were

Table 3 Taxonomic assignment of $d s r \mathrm{~B}$ clones

\begin{tabular}{lllll}
\hline \multirow{2}{*}{ No of clones per samples } & \multirow{2}{*}{ Bacterial genera } & Families \\
\cline { 1 - 2 } PC1 & PD1 & MA240 & & \\
\cline { 1 - 2 } 3 & - & - & Desulfobacterium & Desulfobacteraceae \\
1 & - & - & Desulfobacula & \\
2 & 1 & - & Desulfacinum & \\
- & - & 2 & Desulfococcus & \\
- & - & 2 & Desulfofaba & \\
2 & - & - & Desulfatiferula & \\
- & - & 1 & Desulfosarcina & \\
7 & 2 & 2 & Desulfobulbus & Desulfobulbaceae \\
- & 2 & - & Desulfocapsa & \\
- & - & 1 & Desulforhopalus & \\
1 & 4 & 1 & Desulfomicrobium & Desulfomicrobiaceae \\
1 & 3 & - & Desulfovibrio & Desulfovibrionaceae \\
- & 1 & - & Bilophila & \\
- & 1 & - & Desulfotomaculum & Peptococcaceae \\
2 & - & - & Desulfoarculus & Desulfoarculaceae \\
2 & 10 & 3 & Non-affiliated & Non-affiliated \\
\hline & & & & \\
\hline
\end{tabular}


isolated and related to the Citrobacter, Shewanella, Klebsiella, Aeromonas, and Sulfurospirillum genera. Notably, isolates related to the Citrobacter genus (Enterobacteriaceae) were found to represent 20 and $7 \%$ of total sulfidogenic isolates in the ES and PC stations, respectively (Fig. 5) and can serve as markers for freshwater inputs. Sulfate-reducing strains from ES1 and ES6 samples shared high-sequence similarities with Desulfomicrobium- and Desulfovibrio-related species (Fig. 5; Table S3). In PC station, SRP were only isolated from surface water and were respectively affiliated to Desulfopila- and Desulfotalea-related species. In PD1 and MA240 samples, seven isolates shared high sequence similarity with D. oceani $(98-100 \%)$, while a single isolate was recovered at $800 \mathrm{~m}$ depth and shared high sequence similarity (96\%) with Desulfobacula phenolica (Fig. 5; Table S3). In laboratory, bacterial isolates closely related to $D$. oceani were tested to their ability to cope with oxygen stress. Isolates were incubated in an air-saturated minimal medium and were found to form spheroblast. Moreover, when the bacterial cultures were reinoculated in the initial culture medium under anoxic conditions, no bacterial growth could be detected.

\section{Discussion}

Estuaries are complex ecosystems where aquatic and terrestrial environments are tightly linked. In the present study, we hypothesized that SRP thriving in the anoxic sediments, may be resuspended in the oxic water column and transported through oxic marine-influenced waters. Strong interactions among physical, chemical, and biological processes form strong gradients in the estuarine plume and may help resuspended anaerobes to survive in the water column and even maintain their metabolism within anoxic microniches. Here, total bacterial communities were investigated along a gradient from the concentrated plume of the Adour estuary to marine waters, with a particular interest to SRP. Molecular fingerprinting revealed that the structure and the composition of total bacterial communities varied significantly depending on the distance from the coast and the water depth. The diluted plume samples grouped with marine bacterial communities, whereas the concentrated plume samples were strongly influenced by the estuarine discharges. Combining molecular and cultivation techniques, sulfate-reducing communities were detected in all the sampling stations along the estuary-marine

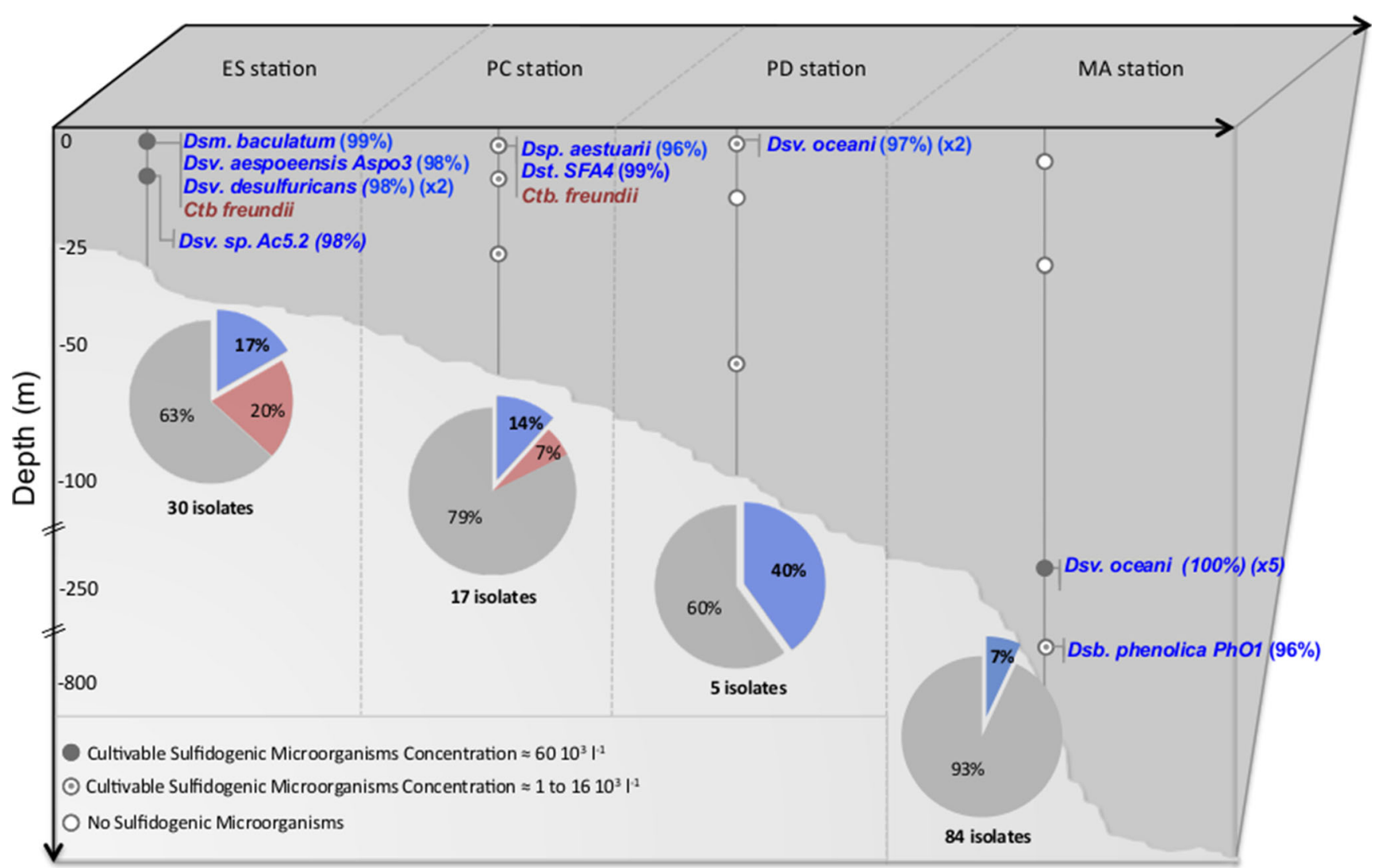

Fig. 5 Spatial distribution of the sulfidogenic microorganisms along the estuary-marine gradient. The abundance of sulfidogenic microorganisms was estimated based on the positive cultures and the dilution rate used for the isolation procedure. Phylogenetic analysis of isolates was performed on partial 16S rRNA gene ( $\sim 600$ bp length). The proportion of SRB identified among sulfidogenic isolates occurring in surface waters (ES1, PC1, PD1, and MA240 samples) is summarized in pie charts. Closest cultured relatives (\% nucleic acid identity) to sulfate-reducing isolates were specified. (Dsm. Desulfomicrobium, Dsv. Desulfovibrio, Dsp. Desulfopila, Dst. Desulfotalea, Dsb Desulfobaca, Ctb. Citrobacter) 
gradient. Even if some microorganisms incapable of sulfate reduction may carry $d s r \mathrm{AB}$ genes $[28,35,51]$, most of clone sequences were phylogenetically related to true SRB. A good agreement was observed between the culture-dependent and independent approaches, since no SRP could be detected at $13 \mathrm{~m}$ water depth in the diluted estuary plume and at 5 and $22 \mathrm{~m}$ water depth in the marine station with both techniques.

Our data suggested that sulfate-reducing communities occurring in coastal waters differed from those inhabiting the diluted estuarine plume and marine bay waters. In the intraestuary station and the concentrated estuarine plume, $d s r \mathrm{~B}$ clone sequences and sulfate-reducing isolates were mostly related to the Desulfobulbaceae, Desulfomicrobiaceae, and Desulfobacteraceae families. A detailed analysis showed that clones related to the Desulfobulbus, Desulfobacula, and Desulfobacterium genera shared high sequence similarities (85-89\%) with $d s r$ B sequences which were previously detected in anoxic sediments, $10 \mathrm{~km}$ upstream of the mouth of the estuary [6]. In addition, sulfate-reducing isolates cultured in the present study and related to Desulfomicrobium baculatum, Desulfovibrio aespoensis, Desulfopila aestuari, and Desulfotalea SFA4 shared high 16S rRNA gene sequence similarities (97-100\%) with sulfate-reducing isolates which were cultured previously in anoxic sediments [6]. These results supported our hypothesis that SRP detected in turbid waters were previously resuspended from upstream sediments and transported in the estuarine plume. Representatives of the Desulfobulbaceae and Desulfobacteraceae families were formerly detected in oxic habitats and exhibited an oxygen tolerance. Notably, Karnachuk et al. [26]) suggested that Desulfobulbaceae members dominate sulfate-reducing communities $(7.8 \%$ of the total number of DAPI-stained cells) inhabiting an oxic zone of a meromictic lake. In addition, SRP affiliated to the Desulfobacter genus were highlighted for their oxygen tolerance in hypersaline microbial mat and were suggested to form cell aggregates to better resist oxidative stress [14].

In addition to common SRP, a significant fraction (7-20\%) of sulfidogenic isolates from ES and PC station shared high $16 \mathrm{~S}$ rRNA gene sequence similarity (96-100\%) with the type strain Citrobacter freundii. Studies on gas pipeline and acid mine drainage indicated that representatives of the genus Citrobacter were able to perform dissimilatory sulfate reduction under anoxic conditions $[1,43]$. Nevertheless, our isolates were not tested for their ability to reduce specifically sulfate. Ferrous sulfide black precipitate observed in our microtiter plates may arise from other oxidized inorganic sulfur compounds such as sulfite, thiosulfate, or elemental sulfur. The strain Citrobacter DBM isolated from sediments of a mining area was found to grow under oxic and anoxic conditions and thus stated as a facultative anaerobe [43]. As consequence, Citrobacter-related microorganisms inhabiting turbid waters of the Adour estuary would probably not be affected by oxygen gradients within the water column. Altogether, these results indicate that representatives of this bacterial genus are good marker for freshwater inputs to the estuarine plume and are suggested to be involved in sulfur cycling in turbid estuarine waters. Nevertheless, further investigations are needed to confirm that Citrobacter constitutes a significant fraction of the sulfatereducing community.

The short incubation period (1-3 weeks) required for the formation of iron sulfide precipitation in the microtiter plate and for bacterial isolation indicated that either SRP were growing in the water column or could recover quickly their growth potential when optimal growth conditions were provided. Sediment particles were previously demonstrated to constitute favorable microniches for anaerobes in oxic habitats. Indeed, in oxic surface sediments, the time required to destroy $90 \%$ of the viable SRP population was extended at least 2-fold for those living associated with large sediment particles (pellets of size $>10 \mu \mathrm{m}$ ) compared those occurring in the $<10$ - and the $<5-\mu \mathrm{m}$ fractions [15]. In the Adour estuary, sediment particles were largely remobilized in the water column of the intra-estuarine station and the concentrated plume and undoubtedly helped SRP to cope with the oxic stress. Stoichev et al. [49] show that almost half of resuspended particles in the Adour estuarine plume were larger than $50 \mu \mathrm{m}$. This particle size was formerly reported sufficient to sustain anoxic or at least hypoxic conditions in such microenvironments [23]. Moreover, the residence time of water and particles in the Adour estuarine plume has been estimated between few hours to several days [41]. Within such time period, SRP related to the Desulfovibrionaceae and Desulfobacteraceae families, maintained in sediments slurries as well as in pure cultures, were formerly distinguished for their tolerance to saturation of dissolved oxygen at $>75 \%$ [8].

Further in the studied gradient, no SRP could be isolated from the water column, except for surface waters of the diluted plume (PD1 samples) as well as at 240 and $800 \mathrm{~m}$ depth in the marine station (MA240 and MA800 samples) where few SRP were cultured. In contrast to coastal waters, most of sulfate-reducing isolates were affiliated to the genus Desulfovibrio. This result may be partly explained by the dilution of suspended particulate matter and their associated microorganisms which are mixed with marine waters (SPM $<1 \mathrm{mg} \mathrm{L}^{-1}$ ). In addition, increasing salinity from estuarine mouth to marine waters represents a key structuring factor in shaping bacterial populations in the Adour estuary, as previously described by Goñi-Urriza et al. [17]. Indeed, salinity reached 31-35 PSU in PD and MA samples, while most of the SRP isolated from estuarine ecosystems exhibit a salinity optimum of 5 or 10 PSU [9, 29]. Desulfovibrio-related bacteria are stated as opportunists and versatile [42], and marine strains show optimal growth between 25 and 35 PSU [13, 19, 50]. Several studies demonstrated oxygen tolerance by Desulfovibrio species in various ecosystems [8, 20, 27, 33]. Sulfate-reducing isolates retrieved from PD1 and MA240 samples are closely related to $D$. oceani, which the type strain (I.8.1 ${ }^{\mathrm{T}}$ ) has been isolated from the water column of an oxygen minimum zone off the coast of Peru at $400 \mathrm{~m}$ depth and that is able to 
survive to oxic stress [13]. Molecular signatures of clones phylogenetically closely related to $D$. oceani were also detected in the water column of the Western English Channel, suggesting the widespread and the general occurrence of autochthonous Desulfovibrio-related microorganisms in marine oxic waters. In our study, $D$. oceani isolates were tested for their ability to cope with oxygen stress but no particular resistance was observed in pure culture. Certain microorganisms exhibit intrinsic oxygen resistance while some others may resist to oxic conditions when occurring in a consortium-like partnership with heterotrophic bacteria [46].

Water collected at $240 \mathrm{~m}$ depth in the marine station constituted a particular sample where high turbidity and high concentrations of ammonium, nitrate, and silica were reported. Moreover, bacterial diversity in the MA240 sample was significantly increased compared with other samples. The increase of these chemical parameters, suggest an advanced decomposition of organic and is presumed to be the result of dead phytoplankton sinking throughout the water column, an aftermath of a massive bloom [18]. Interestingly, sampling was performed following a bloom event in the Adour estuary [36]. Aging phytoplankton aggregates represent favorable sites for bacterial colonization, where a sufficient amount of degradable material is provided for intense heterotrophic bacterial activity. The existence of microniches in cyanobacterial aggregates has been proved experimentally in several studies $[2,39,45]$ and was suggested to play a key role in nitrogen and sulfur cycling. Notably, Michotey and Bonin [32] demonstrated that denitrification, an oxygen-sensitive microbial process, was performed in particle-associated bacterial populations in the Mediterranean Sea. More recently, Canfield et al. [5] reported sulfate reduction and sulfur oxidation activities in oxygen minimum zone waters off the Chilean coast. These authors suggested that the sulfur and the nitrogen cycles are intimately coupled in this ecosystem. In our study, the increased concentration of viable sulfidogenic bacteria at $240 \mathrm{~m}$ water depth, including some SRP and several facultative anaerobic sulfur-metabolizing isolates related to the Shewanella genus, might suggest the formation of hypoxic or anoxic microniches and an active sulfur cycle in deep waters offshore.

\section{Conclusion}

This polyphasic work permitted to detect sulfate-reducing communities along an estuarine to marine gradient. Differential SRP communities were detected from the estuarine mouth to surface marine waters. Those identified in the coastal area are suggested to arise from resuspended sediments and to manage oxic stress within large suspended particles. These anaerobes might even sustain a minimal metabolic activity across the river system influenced by freshwater inputs. In the diluted estuarine plume and in marine bay waters, the SRP concentration was low and this functional group was represented by salt-tolerant autochtonous sulfate-reducing microorganisms, related to the Desulfovibrio species. As reported in Finster and Kjeldsen [13] and Canfield et al. [5], these SRP may grow in oxygen minimum zones where nutrient-rich upwelled water support blooms of phytoplankton and promote short-term anoxic conditions.

Acknowledgments Y.C. was supported by a French Ministry of Education and Investigation grant. This work was partially funded through the ANR project IDEA. The CNRS (INSU) is acknowledged for providing field campaign facilities.

\section{References}

1. Angeles-Ch C, Mora-Mendoza JL, Garcia-Esquivel R et al (2002) Microbiologically influenced corrosion by Citrobacter in sour gas pipelines. Mater Perform 41:50-55

2. Bianchi M, Marty D, Teyssie JL, Fowler SW (1992) Strictly aerobic and anaerobic-bacteria associated with sinking particulate matter and zooplankton fecal pellets. Mar Ecol Prog Ser 88:55-60

3. Borsuk ME, Higdon D, Stow CA, Reckhow KH (2001) A Bayesian hierarchical model to predict benthic oxygen demand from organic matter loading in estuaries and coastal zones. Ecol Model 143:165-181

4. Canfield DE, Des Marais DJ (1991) Aerobic sulfate reduction in microbial mats. Science 251:1471-1473

5. Canfield DE, Stewart FJ, Thamdrup B et al (2010) A cryptic sulfur cycle in oxygen-minimum-zone waters off the Chilean coast. Science 330:1375-1378

6. Colin Y, Goñi-Urriza M, Caumette P, Guyoneaud R (2013) Combination of high throughput cultivation and dsrA sequencing for assessment of sulfate-reducing bacteria diversity in sediments. FEMS Microbiol Ecol 83:26-37

7. Cypionka H (2000) Oxygen respiration by Desulfovibrio species 1 . Ann Rev Microbiol 54:827-848

8. Cypionka H, Widdel F, Pfennig N (1985) Survival of sulfatereducing bacteria after oxygen stress, and growth in sulfate-free oxygen-sulfide gradients. FEMS Microbiol Lett 31:39-45

9. Dias M, Salvado JC, Monperrus M et al (2008) Characterization of Desulfomicrobium salsuginis sp. nov. and Desulfomicrobium aestuarii sp. nov., two new sulfate-reducing bacteria isolated from the Adour estuary (French Atlantic coast) with specific mercury methylation potentials. Syst Appl Microbiol 31:30-37

10. Diaz RJ, Rosenberg R (1995) Marine benthic hypoxia: a review of its ecological effects and the behavioural responses of benthic macrofauna. Oceanogr Mar Biol Annu Rev 33:245-03

11. Etcheber H, Taillez A, Abril G et al (2007) Particulate organic carbon in the estuarine turbidity maxima of the Gironde, Loire and Seine estuaries: origin and lability. Hydrobiologia 588:245-259

12. Falkowski PG, Hopkins TS, Walsh JJ (1980) Analysis of factors affecting oxygen depletion in the New York Bight. J. Mar. Res.;(United States) 38

13. Finster KW, Kjeldsen KU (2010) Desulfovibrio oceani subsp. oceani sp. nov., subsp. nov. and Desulfovibrio oceani subsp. galateae subsp. nov., novel sulfate-reducing bacteria isolated from the oxygen minimum zone off the coast of Peru. Antonie Van Leeuwenhoek 97:221-229

14. Fourçans A, Ranchou-Peyruse A, Caumette P, Duran R (2007) Molecular analysis of the spatio-temporal distribution of sulfatereducing bacteria (SRB) in Camargue (France) hypersaline microbial Mat. Microb Ecol 56:90-100. doi:10.1007/s00248-007-9327-x

15. Fukui M, Takii S (1990) Survival of sulfate-reducing bacteria in oxic surface sediment of a seawater lake. FEMS Microbiol Ecol $6: 317-322$ 
16. Giloteaux L, Goñi-Urriza M, Duran R (2010) Nested PCR and new primers for analysis of sulfate-reducing bacteria in low-cellbiomass environments. Appl Environ Microbiol 76:2856-2865

17. Goni-Uriza MS, Point D, Amouroux D et al (2007) Bacterial community structure along the Adour estuary (French Atlantic coast): influence of salinity gradient versus metal contamination. Aquat Microb Ecol 49:47-56

18. Gooday AJ, Turley CM, Allen JA (1990) Responses by benthic organisms to inputs of organic material to the ocean floor: a review [and Discussion\$\} \$. Philos Trans Royal Soc Lond A: Math, Phys Eng Sci 331:119-138

19. Haouari O, Fardeau M-L, Casalot L et al (2006) Isolation of sulfatereducing bacteria from Tunisian marine sediments and description of Desulfovibrio bizertensis sp. nov. Int J Syst Evol Microbiol 56: 2909-2913

20. Hardy JA, Hamilton WA (1981) The oxygen tolerance of sulfatereducing bacteria isolated from North Sea waters. Curr Microbiol 6: 259-262

21. Ito T, Okabe S, Satoh H, Watanabe Y (2002) Successional development of sulfate-reducing bacterial populations and their activities in a wastewater biofilm growing under microaerophilic conditions. Appl Environ Microbiol 68:1392-1402

22. Jonkers HM, Koh I-O, Behrend P et al (2005) Aerobic organic carbon mineralization by sulfate-reducing bacteria in the oxygensaturated photic zone of a hypersaline microbial mat. Microb Ecol 49:291-300

23. Jørgensen BB (1977) Bacterial sulfate reduction within reduced microniches of oxidized marine sediments. Mar Biol 41:7-17. doi:10.1007/BF00390576

24. Jørgensen BB (1982) Mineralization of organic matter in the sea bed-the role of sulphate reduction. Nature 296:643-645

25. Junier P, Junier T, Witzel K-P (2008) TRiFLe, a program for in silico terminal restriction fragment length polymorphism analysis with user-defined sequence sets. Appl Environ Microbiol 74:6452_ 6456

26. Karnachuk OV, Pimenov NV, Yusupov SK et al (2006) Distribution, diversity, and activity of sulfate-reducing bacteria in the water column in Gek-Gel Lake, Azerbaijan. Microbiology 75: 82-89

27. Kjeldsen KU, Joulian C, Ingvorsen K (2004) Oxygen tolerance of sulfate-reducing bacteria in activated sludge. Environ Sci Technol 38:2038-2043

28. Klein M, Friedrich M, Roger AJ et al (2001) Multiple lateral transfers of dissimilatory sulfite reductase genes between major lineages of sulfate-reducing prokaryotes. J Bacteriol 183:6028-6035

29. Knoblauch C, Sahm K, Jørgensen BB (1999) Psychrophilic sulfatereducing bacteria isolated from permanently cold Arctic marine sediments: description of Desulfofrigus oceanense gen. nov., sp. nov., Desulfofrigus fragile sp. nov., Desulfofaba gelida gen. nov., sp. nov., Desulfotalea psychrophila gen. nov., sp. nov. and Desulfotalea arctica sp. nov. Int J Syst Evol Microbiol 49:16311643

30. Lê S, Josse J, Husson F (2008) FactoMineR: an R package for multivariate analysis. J Stat Softw 25:1-18

31. Marchesi JR, Sato T, Weightman AJ et al (1998) Design and evaluation of useful bacterium-specific PCR primers that amplify genes coding for bacterial 16S rRNA. Appl Environ Microbiol 64:795799

32. Michotey V, Bonin P (1997) Evidence for anaerobic bacterial processes in the water column: denitrification and dissimilatory nitrate ammonification in the northwestern Mediterranean Sea. Mar Ecol Prog Ser 160:47-56
33. Mogensen GL, Kjeldsen KU, Ingvorsen K (2005) Desulfovibrio aerotolerans sp. nov., an oxygen tolerant sulphate-reducing bacterium isolated from activated sludge. Anaerobe 11:339-349

34. Nocker A, Lepo JE, Martin LL, Snyder RA (2007) Response of estuarine biofilm microbial community development to changes in dissolved oxygen and nutrient concentrations. Microb Ecol 54: $532-542$

35. Nonaka H, Keresztes G, Shinoda Y et al (2006) Complete genome sequence of the dehalorespiring bacterium Desulfitobacterium hafniense Y51 and comparison with Dehalococcoides ethenogenes 195. J Bacteriol 188:2262-2274

36. Novoa S, Chust G, Sagarminaga Y, et al. (2012) Chlorophyll-waters and the Bay of Biscay, between 2005 and 2010, using MODIS imagery. Revista de Investigacion Marina

37. Oksanen J, Kindt R, Legendre P, et al. (2007) The vegan package. Community ecology package 10

38. Paerl HW, Pinckney JL, Fear JM, Peierls BL (1998) Ecosystem responses to internal and watershed organic matter loading: consequences for hypoxia in the eutrophying Neuse River Estuary, North Carolina, USA. Mar Ecol Prog Ser 166:17

39. Ploug H, Kühl M, Buchholz B, Jørgensen BB (1997) Anoxic aggregates an ephemeral phenomenon in the ocean. Aquat Microb Ecol 13:285-294

40. Plugge CM, Zhang W, Scholten JCM, Stams AJM (2011) Metabolic flexibility of sulfate-reducing bacteria. Front Microbiol

41. Point D, Bareille G, Amouroux D et al (2007) Reactivity, interactions and transport of trace elements, organic carbon and particulate material in a mountain range river system (Adour River, France). J Environ Monit 9:157-167

42. Purdy KJ, Nedwell DB, Embley TM, Takii S (1997) Use of 16S rRNA-targeted oligonucleotide probes to investigate the occurrence and selection of sulfate-reducing bacteria in response to nutrient addition to sediment slurry microcosms from a Japanese estuary. FEMS Microbiol Ecol 24:221-234

43. Qiu R, Zhao B, Liu J et al (2009) Sulfate reduction and copper precipitation by a Citrobacter sp. isolated from a mining area. $\mathrm{J}$ Hazard Mater 164:1310-1315

44. Schramm A, Santegoeds CM, Nielsen HK et al (1999) On the occurrence of anoxic microniches, denitrification, and sulfate reduction in aerated activated sludge. Appl Environ Microbiol 65:4189-4196

45. Shanks AL, Reeder ML (1993) Reducing microzones and sulfide production in marine snow. Mar Ecol Prog Ser 96:43-47

46. Sigalevich P, Baev MV, Teske A, Cohen Y (2000) Sulfate reduction and possible aerobic metabolism of the sulfate-reducing bacterium Desulfovibrio oxyclinae in a chemostat coculture with Marinobacter sp. strain MB under exposure to increasing oxygen concentrations. Appl Environ Microbiol 66:5013-5018

47. Smith CJ, Danilowicz BS, Clear AK et al (2005) T-Align, a webbased tool for comparison of multiple terminal restriction fragment length polymorphism profiles. FEMS Microbiol Ecol 54:375-380

48. Stanley DW, Nixon SW (1992) Stratification and bottom-water hypoxia in the Pamlico River. Springer. http://link.springer. com/article/10.2307/1352775\#page-1. Accessed 13 Apr 2016

49. Stoichev T, Amouroux D, Wasserman JC et al (2004) Dynamics of mercury species in surface sediments of a macrotidal estuarinecoastal system (Adour River, Bay of Biscay). Estuar Coast Shelf Sci 59:511-521

50. Takii S, Hanada S, Hase Y et al (2008) Desulfovibrio marinisediminis sp. nov., a novel sulfate-reducing bacterium isolated from coastal marine sediment via enrichment with Casamino acids. Int J Syst Evol Microbiol 58:2433-2438

51. Zverlov V, Klein M, Lücker S et al (2005) Lateral gene transfer of dissimilatory (bi)sulfite reductase revisited. J Bacteriol 187:2203-2208 